\title{
Scenario of ovarian mass lesions at a teaching hospital in Andhra Pradesh, India
}

\author{
Soumini Gangaraju ${ }^{1 *}$, Lavanya Kumari Sarella ${ }^{1}$, Lakshmi Chaveli V², \\ Sandhya Gurugubelli ${ }^{4}$
}

\begin{abstract}
${ }^{1}$ Department of Obstetrics \& Gynaecology, ${ }^{2}$ Department of Pathology, Rangaraya Medical College, Kakinada, Andhra Pradesh-533001, India
\end{abstract}

Received: 21 April 2015

Revised: 22 May 2015

Accepted: 04 June 2015

\section{*Correspondence:}

Dr. Soumini Gangaraju,

E-mail: doctorsoumini@yahoo.co.in

Copyright: (c) the author(s), publisher and licensee Medip Academy. This is an open-access article distributed under the terms of the Creative Commons Attribution Non-Commercial License, which permits unrestricted non-commercial use, distribution, and reproduction in any medium, provided the original work is properly cited.

\begin{abstract}
Background: Ovary is the common site of non-neoplastic and neoplastic lesions which accounts for significant morbidity and mortality. The objective of present study was to ascertain the frequency and distribution of the various non-neoplastic and neoplastic ovarian mass lesions and to study the clinical and histopathological presentation.

Methods: Observational study of cases with ovarian mass lesions subjected to surgical management from September 2009-August 2014 at our centre Government General Hospital/RMC Kakinada.

Results: Incidence of ovarian masses was $(n=404) 4.66 \%$ in 8,656 admissions subjected to surgical management. There were (340/404) 84.16\% neoplasms and (64/404) 15.84\% nonneoplastic lesions. Follicular and simple serous cysts were common non neoplastic lesions. Twisted ovarian cyst was the commonest surgical emergency. Age of the patients ranged from 9years to 82years. Mean ages of non-neoplastic, benign and malignant lesions were 34.2years, $36.8 y e a r s$ and 44.7yrs.Most of the cases were in reproductive agegroup $(\mathrm{p}<0.001)$. Benign neoplasms were $(248 / 340)$ $72.94 \%$, borderline (26/340) $7.64 \%$ and malignant neoplasms were (66/340) $19.41 \%$. Surface epithelial tumours dominated other types $(78.12 \%)$ followed by germ cell tumours $(12.05 \%)$ and sex cord stromal tumours $(6.47 \%)$. Mucinous cystadenoma $(34.11 \%)$ was the commonest benign tumour, followed by serouscystadenoma $23.53 \%$. Commonest malignant ovarian tumour was serous cystadenocarcinoma (9.11\%).

Conclusion: Ovarian neoplasms were more common than non-neoplasms subjected to surgical management. Surface epithelial tumours were the commonest neoplasms with more benign neoplasms. Commonest benign neoplasm was mucinous cystadenoma and malignant was serous cystadenocarcinoma. Significant number of malignant ovarian tumors presented at an earlier age and in late stages.
\end{abstract}

Keywords: Ovarian neoplasm, Non-neoplasm, Clinical evaluation, Histopathology

\section{INTRODUCTION}

Ovarian cancer is the most lethal gynaecological cancer. Worldwide, 2,39,000 new cases of ovarian cancer and estimated deaths of 1,52,000 are recorded in 2014. ${ }^{1}$ Age adjusted incidence rates(AAR) ranged from 11 per 100000 women in Central Europe to 5 per 100000 women in Africa. ${ }^{2}$. Estimated new cases and deaths of ovarian cancer in the United States in 2015 is 21,290 and
14,180 with lifetime risk of about $1.33 \%$ and AAR of 11.4 per100000 women. ${ }^{3}$ In England and Wales, it is fifth most common cancer with estimated life time risk of $1.66 \%$ and AAR of 9.4 per 100000 population. ${ }^{4}$ It is the fourth most common cancer in women in India. ${ }^{5}$ Indian cancer registry data in 2011 projects AAR of ovarian cancer from 10.7-1.2 per100000 in different parts of the country with the highest incidence in Kamrup urban district and Delhi registries. ${ }^{6}$ 
In spite of all the advances made in diagnosis and treatment, ovarian carcinoma remains the leading cause of gynaecological disease mortality. The ovaries are relatively inaccessible with unknown precursor lesions. It is a heterogeneous disease with low and high grade subtypes and widely differing clinicopathologic features which develop independently along different molecular pathways. Both types develop outside the ovary and involve it secondarily. This explains why current screening strategies designed to detect ovarian cancer, when it is confined to the ovary, are ineffective in accomplishing this goal. ${ }^{7}$ So this study was undertaken in view of importance of clinicopathological determination in diagnosis, prognosis as well as appropriate management of ovarian tumours at our tertiary care referral hospital.

\section{METHODS}

This was a 5 years observational study from September 2009 to August 2014 in the Department of Obstetrics and Gynaecology, Rangaraya Medical College, Kakinada, AP, South India. All cases with ovarian mass lesions treated surgically were included in the study. The diagnostic evaluation was done with investigations for exclusion of malignancy with USG, tumour markers, CT and MRI wherever indicated. Clinical details of the patients included age, gynaecological \&obstetric history, presenting symptoms, and surgery details. Histopathalogical reporting was done at our Pathology department. The lesions were categorised as non-neoplastic and neoplastic and analysed. The histological characterisation of ovarian tumour was done according to World Health Organization Classification of Ovarian tumours.

\section{Statistical Methods}

Descriptive statistics and Pearson Chi-square test were used to describe the study sample with Microsoft Excel software and SPSS 16.

\section{RESULTS}

Incidence of ovarian masses was $4.66 \%(n=404)$ in 8,656 admissions subjected to surgery. $84.16 \%$ were neoplastic,
15.84\% non-neoplastic. Among neoplasms (248/340) $72.94 \%$ were benign tumours, 26(7.64\%) were borderline and $66(19.41 \%)$ were malignant ovarian tumours (Figure $1)$. Age of the patients ranged from 9years to 82 years. Mean ages for non-neoplastic, benign and malignant were 35.9, 36.8, and 44.7 years. Benign lesions were more common in 30-40years, and malignant lesions in 40-59 years age (Table 1$)$.



Figure 1: Distribution of ovarian masses. Neoplasms \& non neoplastic lesions.

Non neoplastic lesions were $64(15.84 \%)$ with follicular cyst as commonest (Figure 2). Twisted ovarian cyst with both non-neoplastic and neoplastic tumours was the commonest surgical emergency $(5.91 \%)$, followed by ruptured corpus luteal cysts $(1.33 \%)$. There were 2 cases of torsion in the adolescents and 20 cases in the reproductive women in whom one was antenatal, two puerpural, one case was in postmenopausal age group (Figure 3).

Demographic \& clinical Profile of patients is shown in (Table 2). The commonest presenting symptom was pain abdomen and mass abdomen and menstrual abnormalities in non-neoplastic and benign neoplasms. Vague abdominal and constitutional symptoms were more in malignant cases. Thyrotoxicosis, virilisation, hirsutism hoarseness of voice, menstrual abnormalities including postmenopausal bleeding were more in hormone secreting sex cord stromal and germ cell tumours. Pleural effusion was seen with fibroma (Table 3).

Table 1: Distribution of ovarian masses in various age groups of patients with both non-neoplastic and neoplastic ovarian masses.

\begin{tabular}{|llllll|}
\hline $\begin{array}{l}\text { Age in } \\
\text { years }\end{array}$ & $\begin{array}{l}\text { Non-neoplasms } \\
<10\end{array}$ & $\begin{array}{l}\text { Benign } \\
\text { neoplasms }\end{array}$ & $\begin{array}{l}\text { Borderline } \\
\text { neoplasms }\end{array}$ & $\begin{array}{l}\text { Malignant } \\
\text { neoplasms }\end{array}$ & $\begin{array}{l}\text { Total } \\
0(1.5 \%)\end{array}$ \\
\hline $10-19$ & $4(6.3 \%)$ & $19(7.66 \%)$ & $0(0.00 \%)$ & $1(1.52 \%)$ & $2(0.50 \%)$ \\
\hline $20-29$ & $17(26.6 \%)$ & $37(14.91 \%)$ & $2(7.69 \%)$ & $3(4.55 \%)$ & $27(6.68 \%)$ \\
\hline $30-39$ & $19(29.6 \%)$ & $84(33.87 \%)$ & $6(23.08 \%)$ & $7(12.12 \%)$ & $64(15.84 \%)$ \\
\hline $40-49$ & $15(23.4 \%)$ & $59(23.79 \%)$ & $7(26.92 \%)$ & $18(27.27 \%)$ & $124(30.69 \%)$ \\
\hline $50-59$ & $3(4.6 \%)$ & $26(10.48 \%)$ & $5(19.23 \%)$ & $15(22.73 \%)$ & $49(12.13 \%)$ \\
\hline $60-69$ & $4(6.3 \%)$ & $17(6.85 \%)$ & $3(11.54 \%)$ & $11(16.67 \%)$ & $35(8.66 \%)$ \\
\hline$>70$ & $1(1.5 \%)$ & $6(2.41 \%)$ & $2(7.69 \%)$ & $3(4.55 \%)$ & $12(2.97 \%)$ \\
\hline Total & $64(100 \%)$ & $248(100 \%)$ & $26(100.00 \%)$ & $66(100.00 \%)$ & $404(100.00 \%)$ \\
\hline
\end{tabular}




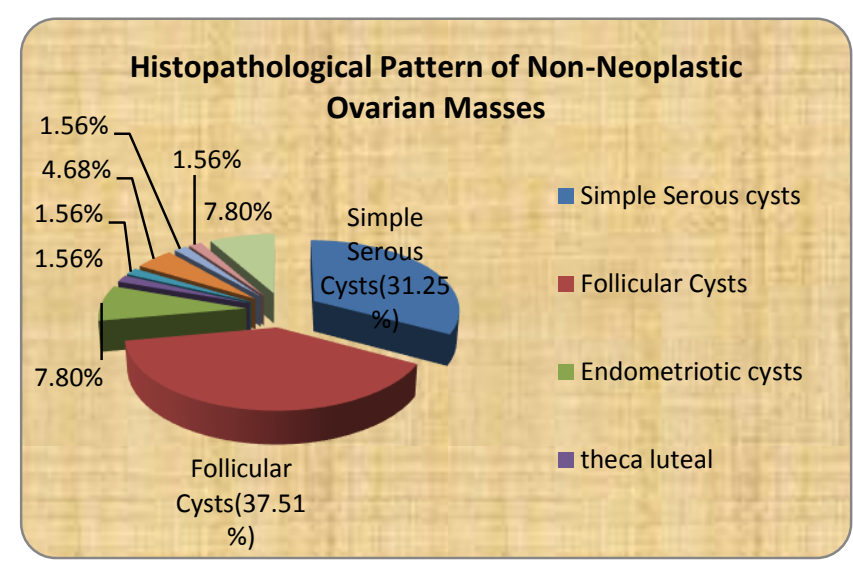

Figure 2: Histopathological pattern of non-neoplastic ovarian mass lesions.

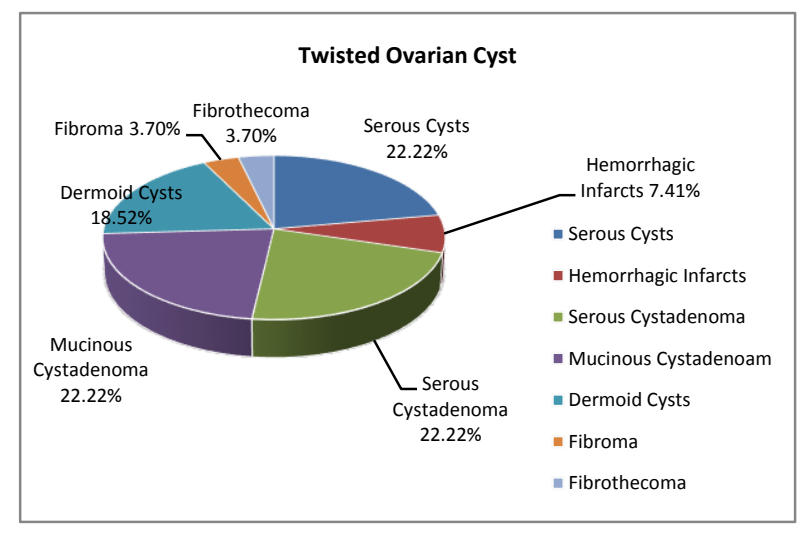

Figure 3: Histopathological pattern of lesions in twisted ovarian cyst.
Surface epithelial tumours were $78.12 \%$ (268/340) dominated others, with commonest benign neoplasm as mucinous cystadenoma $34.11 \%(116 / 340)$ followed by serous cystadenoma $25.29 \%(86 / 340)$ and malignant as serous cystadenocarcinoma $(9.95 \%)$, mucinous cystadenocarcinoma $(2.72 \%)$. There were 2 cases of malignant Brenner tumour and one endometroid tumour. Germ cell tumours formed (41/340) $12.05 \%$, majority $(80 \%)$ of cases were benign mature cystic teratomas. The malignant germ cell tumours were $6(1.76 \%$ ) cases of dysgerminoma, and $3(0.88 \%)$ cases of endodermal sinus tumor. Sexcordstromal tumors were $6.47 \%$, with 6 cases granulosa cell \& one sertolileydig as malignant and seven cases each of fibromas, fibrothecomas as benign. One metastasis was from colonic carcinoma (Table 4).

Most of the Germ cell tumours were diagnosed at early stage and all the Surface epithelial tumors were diagnosed mostly in stage III and IV (84\%). For malignant neoplasms surgical staging laparotomy (TAH with BSO and omentectomy) was done in 16 cases, debulking and chemotherapy in 24 cases, neo-adjuvant chemotherapy with cytoreductive surgery in 6 cases and palliative chemotherapy in 4 cases. 6 cases were operated for recurrence. Fertility-sparing surgical measures, such as unilateral salpingo-oophorectomy was done in stage 1 tumours in juvenile granulosa cell tumours, yolksac tumour in adolescents and also in one case of Sertolileydig cell tumour, who delivered at term gestation. Follow up of malignant ovarian tumours was inadequate with reported 12 deaths.

Table 2: Gynaecological and obstetric profile of ovarian mass lesions.

\begin{tabular}{|c|c|c|c|c|}
\hline Catogery & $\begin{array}{l}\text { Non } \\
\text { neoplastic }\end{array}$ & $\begin{array}{l}\text { Benign } \\
\text { Neoplasia }\end{array}$ & $\begin{array}{l}\text { Boderline } \\
\text { Neoplasia }\end{array}$ & $\begin{array}{l}\text { Malignant } \\
\text { Neoplasia }\end{array}$ \\
\hline \multicolumn{5}{|l|}{ Age } \\
\hline Pre menarcheal & 1 & 2 & 0 & 1 \\
\hline Adolescent & 3 & 12 & 1 & 3 \\
\hline Reproductive & 60 & 186 & 19 & 33 \\
\hline Postmenopausal & 1 & 48 & 6 & 29 \\
\hline \multicolumn{5}{|l|}{ Menstual History } \\
\hline Regular & 42 & 148 & 20 & 38 \\
\hline AUB & 6 & 12 & 2 & 8 \\
\hline Postmenopausal Bleeding & 0 & 2 & 1 & 2 \\
\hline Contraceptive H/o Tubectomised & 48 & 146 & 12 & 32 \\
\hline \multicolumn{5}{|l|}{ Parity } \\
\hline -nulli & 12 & 10 & 3 & 6 \\
\hline$-\mathrm{P} 1, \mathrm{P} 2$ & 28 & 156 & 11 & 26 \\
\hline$-\mathrm{P} 3 \&>$ & 24 & 82 & 10 & 34 \\
\hline \multicolumn{5}{|l|}{ Gynaec Surgeries } \\
\hline Hysterectomy & 6 & 5 & 1 & 4 \\
\hline Ovarian cystectomy & 0 & 0 & 1 & 1 \\
\hline
\end{tabular}

In Reproductive age group $(\mathrm{P}<0.001)$ Menstrual history $(\mathrm{p}>0.05)$ ns MultiParity $(\mathrm{P}<0.001)$ 
Table 3: Clinical presentation of ovarian masses.

\begin{tabular}{|llll|} 
Symptoms & Non-neoplasms & $\begin{array}{l}\text { Benign } \\
\text { neoplasms }\end{array}$ & $\begin{array}{l}\text { Malignant } \\
\text { neoplasms }\end{array}$ \\
\hline Pain abdomen & $42 / 64 ; 66.00 \%$ & $217 / 340 ; 64.00 \%$ & $48 / 66 ; 76.00 \%$ \\
\hline Mass abdomen & $0.00 \%$ & $272 / 340 ; 80.00 \%$ & $56 / 66 ; 86.00 \%$ \\
\hline Abdominal symptoms & $1.00 \%$ & $53.00 \%$ & $94.55 \%$ \\
\hline Menstrual symptoms & $46.00 \%$ & $28.00 \%$ & $18.00 \%$ \\
\hline Urinary symptoms & $0.00 \%$ & $12.00 \%$ & $22.00 \%$ \\
\hline Constitutional & $0.00 \%$ & $4.00 \%$ & $32.00 \%$ \\
\hline Asymptomatic & $2.00 \%$ & $15.00 \%$ & $0.00 \%$ \\
\hline $\begin{array}{l}\text { Others -mass PV ,GI } \\
\text { Symptoms, bowelobst }\end{array}$ & $2.00 \%$ & $6.00 \%$ & $8.00 \%$ \\
\hline
\end{tabular}

Table 4: Histopathological pattern of neoplastic ovarian masses.

\begin{tabular}{|c|c|c|c|}
\hline & & Number & Percentage \\
\hline I. Surface epithelial tumors & & total 268 & $78.82 \%$ \\
\hline \multirow[t]{4}{*}{ serous } & total & 125 & $36.76 \%$ \\
\hline & benign & 86 & $25.29 \%$ \\
\hline & borderline & 8 & $2.35 \%$ \\
\hline & malignant & 31 & $9.11 \%$ \\
\hline \multirow[t]{4}{*}{ mucinous } & total & 139 & $40.88 \%$ \\
\hline & benign & 116 & $34.11 \%$ \\
\hline & borderline & 18 & $5.26 \%$ \\
\hline & malignant & 5 & $1.47 \%$ \\
\hline endometroid & & 2 & $0.57 \%$ \\
\hline clear cell & & 0 & $0.00 \%$ \\
\hline transitional cellcarcinoma & Brenner & 2 & $0.57 \%$ \\
\hline II. Germ cell tumours & & 41 & $12.05 \%$ \\
\hline \multirow[t]{3}{*}{ Teratoma } & total & 30 & $8.82 \%$ \\
\hline & benign & 30 & $8.82 \%$ \\
\hline & malignant & 0 & $0.00 \%$ \\
\hline Embryonal carcinoma & & 1 & $0.29 \%$ \\
\hline $\begin{array}{l}\text { yolk sac tumour } 2 \\
\text { endodermal sinus tumour1 }\end{array}$ & & 3 & $0.88 \%$ \\
\hline Dysgerminoma & & 6 & $1.76 \%$ \\
\hline Mixed germ cell tumour & & 1 & $0.29 \%$ \\
\hline III. Sex cord stromal tumours & & 22 & $6.47 \%$ \\
\hline Granulosa cell tumour & & 6 & $1.76 \%$ \\
\hline Sclerosing stromal tumour & & 1 & $0.29 \%$ \\
\hline Sertolileydig cell tumour & & 1 & $0.29 \%$ \\
\hline \multicolumn{4}{|l|}{ Benign } \\
\hline Fibrothecoma & & 7 & $2.05 \%$ \\
\hline Fibroma & & 7 & $2.05 \%$ \\
\hline \multicolumn{4}{|l|}{ IV. Others } \\
\hline Metastasis & & 1 & $0.29 \%$ \\
\hline
\end{tabular}


Table 5: Comparative incidence of benign, borderline and malignant primary ovarian neoeplasms.

\begin{tabular}{|c|c|c|c|c|c|c|}
\hline $\begin{array}{l}\text { STUDY } \\
\text { Author }\end{array}$ & $\begin{array}{l}\text { Present } \\
\text { Study }\end{array}$ & $\begin{array}{l}\text { Dr.M.Yogamba } \\
\text { letal }^{12}\end{array}$ & $\begin{array}{l}\text { HardikMakwan } \\
\text { al }^{13}\end{array}$ & Bista KDB ${ }^{14}$ & $\begin{array}{l}\text { Layla S. } \\
\text { Abdullah }^{15}\end{array}$ & $\begin{array}{l}\text { Samina } \\
\text { Zamanll }^{16}\end{array}$ \\
\hline $\begin{array}{l}\text { Place of } \\
\text { study }\end{array}$ & $\begin{array}{l}\text { Ragaraya } \\
\text { Medical } \\
\text { College, } \\
\text { Kakinada } \\
\text { India }\end{array}$ & $\begin{array}{l}\text { Stanley Medical } \\
\text { College Chennai } \\
\text { India }\end{array}$ & $\begin{array}{l}\text { Shah Medical } \\
\text { College, Gujarat. } \\
\text { India }\end{array}$ & $\begin{array}{l}\text { Tribhuvan } \\
\text { University } \\
\text { Teaching } \\
\text { Hospital, } \\
\text { Kathmandu, } \\
\text { Nepal }\end{array}$ & $\begin{array}{l}\text { King Abdulaziz } \\
\text { University, } \\
\text { Jeddah, } \\
\text { SaudiArabia }\end{array}$ & $\begin{array}{l}\text { Post } \\
\text { Graduate } \\
\text { Medical } \\
\text { Institute, } \\
\text { Lahore } \\
\text { Pakistan }\end{array}$ \\
\hline $\begin{array}{l}\text { Period of } \\
\text { study }\end{array}$ & $\begin{array}{l}\text { September } \\
2009 \text {-August } \\
2014\end{array}$ & $\begin{array}{l}\text { Jan2009- } \\
\text { Dec2013 }\end{array}$ & $\begin{array}{l}\text { Jan } 2002 \text { to } \\
\text { Dec2012 }\end{array}$ & April 2009-2012 & $\begin{array}{l}\text { Jan } 1995 \text { and } \\
\text { Dec } 2010\end{array}$ & $\begin{array}{l}\text { Jan- } \\
\text { Dec2008 }\end{array}$ \\
\hline $\begin{array}{l}\text { Number of } \\
\text { cases }\end{array}$ & 404 & 402 & 337 & 451 & 618 & 498 \\
\hline Benign & $72.94 \%$ & $78.6 \%$ & $77.14 \%$ & $82 \%$ & $72.8 \%$ & $78.70 \%$ \\
\hline Boderline & $7.64 \%$ & $0.75 \%$ & $3.57 \%$ & $3.1 \%$ & $5.2 \%$ & $0.64 \%$ \\
\hline Malignant & $19.41 \%$ & $20.65 \%$ & $19.29 \%$ & $14.9 \%$ & $22.0 \%$ & $21.29 \%$ \\
\hline
\end{tabular}

\section{DISCUSSION}

The ovary is a dynamic complex structure in embryology, histology, steroidogenesis, with its potential for malignancy, with its different components like germ cells, follicular cells and mesenchymal tissue each having different capability to form various tumours. Ovarian mass lesions in our study included (340/404) 84.16\% neoplastic, (64/404) $15.84 \%$ non-neoplastic lesions. Neoplasms outnumbered non neoplastic lesions. This was similar to other studies with more neoplastic lesions. ${ }^{8-10}$ differed from others, with more non neoplastic lesions. ${ }^{11,13}$ Benign neoplasms were (248/340) $72.94 \%$, borderline (26/340) $7.64 \%$ and malignant neoplasms (66/340) $19.41 \%$ similar to other studies ${ }^{12-16}$ is shown in Table 5 .

Non-neoplastic lesions are the common causes of ovarian enlargement with possibly hormonally active follicular and luteal cysts or inactive serous cysts as classified by Blaustein. ${ }^{17}$ In our study follicularcysts $(37.15 \%)$ were most common followed by simple serous $(30 \%)$, endometriotic cysts $(9.37 \%)$, corpusluteal cysts $(7.80 \%)$. In other studies luteal cysts, endometriotic cysts were common followed by simple serous cyst, ${ }^{8-10}$ follicular and corpus luteal cysts were common followed by serous cysts. ${ }^{11,13}$

Twisted ovarian cyst was commonest surgical emergency in 23 cases $(5.91 \%)$ followed by cyst rupture and haemoperitoneum $(3.12 \%)$. S. Maharjan ${ }^{10}$ observed torsion $(6.7 \%)$, but higher incidence of cysts rupture with haemoperitoneum $(6 \%)$ than in our study. Torsion was present in $65 \%$ cases of neoplasms and $35 \%$ cases of nonneoplastic lesions in our study. Cass et al. ${ }^{18}$ observed torsion in $55 \%$ neoplasms and $47 \%$ non-neoplastic lesions and Manivasakan et al. ${ }^{19}$ observed in $45 \%$ and $53 \%$ respectively.

Our study reveals that the presentation of ovarian tumours is variable. Common symptoms were abdominal mass, pelvic/abdominal pain. Other symptoms are dyspepsia, urinary frequency and urgency, loss of weight and ascites, which are more common in malignant tumours. These findings are in accordance to other studies..$^{8-15,19-21}$

Benign lesions were more common in 30-40 years, and malignant lesions in 40-59 years age group similar to studies of Ameena, Jha. ${ }^{8,20}$ The commonest neoplasms were epithelial tumours seen 12-80 years with peak age at 41-50 yrs. Mean age of malignant tumors is 44.7 years which is nearer to study of Sharada, Bist, Iyoke I,14,21 $^{9}$ between 41-45.4 yr. This is lower than median age of 64 yearsin USA. The variance in age groups being lower in Asians was also observed by Katherine C.Fuh. ${ }^{22}$

Despite the high incidence and mortality rates, the etiology of ovarian cancer is poorly understood. Established risk factors for ovarian cancer include age and having a family history, while protective factors include increasing parity, oral contraceptive use, and oophorectomy. Borderline and malignant tumours were $(73.08 \%) \&(50 \%)$ in reproductive age group $(\mathrm{P}<0.001)$, and more tumours in multiParity $(\mathrm{P}<0.001)$ was statistically significant. There was no family history in malignant neoplasms in our study. There was no history of harmone replacement therapy. Protective effect of multiparity, tubal sterilization and hysterectomy were not significant in our study. Surgeries such as hysterectomy and tubal ligation are said to confer a weak protective effect against ovarian cancer from ascending carcinogens. ${ }^{23}$ Women with ovarian preservation at hysterectomy are at risk for future oophorectomy, which ranges from $2.9 \%$ to $7.7 \% .^{24}$

There has been a growing evidence supporting the fallopian tube as the site of origin of high grade surface epithelial ovarian cancer. The latest opinion of ACOG, 2015 is prophylactic salpingectomy may offer protection instead of oopherectomy in at risk cases of ovarian cancer without hypoestrogenic effects. ${ }^{25}$

In our study surface epithelial tumors were commonest, followed by germ cell tumors, sex cord stromal tumors. 
Benign surface epithelial tumors were the commonest type $(81.17 \%)$ followed by malignant surface epithelial tumour $(15.88 \%)$ comparable to other studies ${ }^{12,16,27}$ but with more borderline ovarian tumors $26(7.64 \%)$ similar to Mondal. ${ }^{26}$ The suface epithelial tumours are subtyped into serous, mucinous, transitional, clear cell, endometroid types. Serous subtype epithelial tumours are commonest benign and malignant neoplasms in literature and various studies. ${ }^{8-12,14,15,17,19-27}$ \&others

Mucinous tumours account for $10-15 \%$ of ovarian tumours but in our study mucinous cystadenomas dominated serous cystadenomas, comprising (139/340) $40.88 \%$ with benign $80.64 \%, 12.82 \%$ borderline and $6.9 \%$ carcinomas. No comparative literature was found with respect to increase in benign mucinous cystadenomas (Table 6). Mucinouscystadenocarcinoma was $6.1 \%$ in Ivy sharma. ${ }^{28}$ study, but less than $4 \%$ in others. $^{26,35,36}$ This diversity may reflect the geographical and ethnic variations as epithelial ovarian cancer is a disease with a pattern of heterogeneous distribution. ${ }^{29}$ In our study the exact cause of risk factors, which may be environmental have to be studied further.

Table 6: Comparative study of common Subtypes of epithelial neoplasms.

\begin{tabular}{|lll|}
\hline STUDY & $\begin{array}{l}\text { Mucinos } \\
\text { tumours }\end{array}$ & $\begin{array}{l}\text { Serous } \\
\text { tumours }\end{array}$ \\
\hline Mondel etal $^{26}$ & $16.30 \%$ & $46.7 \%$ \\
\hline Samina etal $^{16}$ & $20 \%$ & $43.21 \%$ \\
\hline Pilli GS $^{36}$ & $25.2 \%$ & $42.9 \%$ \\
\hline Kuldeepa etal $^{35}$ & $32.35 \%$ & $33.82 \%$ \\
\hline Present study & $40.88 \%$ & $36.76 \%$ \\
\hline
\end{tabular}

Mucinouscystadenomas are associated with dermoid cysts in 3 to $5 \%,{ }^{30}$ suggesting that they may be monodermal teratomas of germ cell origin. In our study 2 cases of mucinous cystadenomas are associated with a dermoid, also reported by others. ${ }^{31,32}$ In our study they were mostly unilateral. They were not subtyped as endocervical and intestinal type. Appedicectomy was also done in 6 cases of mucinous neoplasms and no secondaries were diagnosed. These tumors are related closely to each other and are distinct from other histologic subtypes of epithelial ovarian neoplasms from a clinical, histologic, and also in mutational profiles such as KRAS mutations, but infrequent p53 and BRCA mutations. A continuum appears to be present from benign to borderline to malignant, which is different from other types of epithelial ovarian cancer, which suggests the potential preventability of borderline and invasive mucinous ovarian cancer by surgical excision of identifiable precursor lesions. ${ }^{33}$ In our study there were no mucinouscystadenocarcinomas with malignant transformations. There were 2 cases of endometroid and 2 malignant Brenner tumours $(0.57 \%)$ with no clear cell carcinoma, similar to study of. ${ }^{34}$
Second most common group of ovarian neoplasms, are germ cell tumours. They are counterpart of testicular germ cell tumours. In our study they are $12.05 \%$, consistent with other studies ${ }^{15,27,35}$ lower than than in studies of others. ${ }^{8,11,14,16,26}$ Mature cystic teratoma was the commonest type of germ cell tumour $(80 \%)$ similar to other studies. ${ }^{15}$ It was commonest benign tumour in study by Ameena, Bist and Jha, Pili. ${ }^{8,14,20,36}$ Dysgerminomas accounted to $1.76 \%$ in our study, nearer to others. ${ }^{16,34,35}$ Maharajan ${ }^{10}$ reported dysgerminoma as the commonest malignant ovarian tumour. Functional teratomas such as strumaovari was seen 2 cases, also reported in other studies. ${ }^{16,37,38}$ Torsion was seen in $18.52 \%$.

Sex-cord stromal tumours represent approximately 7\% of ovarian neoplasms, arises from mesenchymal components like steroid producing cells as well as fibroblasts, manifests as unilateral solid mass similar to testicular tumours. Harmonal manifestations are with estrogen producing granulosa cell tumours, testosterone producing SertoliLeydig cell tumours. Fibromas are harmonally inert but can produce complications like torsion and pleural effusion. ${ }^{39}$ These were observed inour study. Torsion occured in $3.76 \%$ in fibromas and fibrothecomas and one case of fibroma presented with pleural effusion. Granulosa cell tumour is the most common oestrogen-producing ovarian tumour. Synchronous endometrial malignancy and endometrial hyperplasia can occur. ${ }^{39}$ In our study, there were both juvenile and adult granulosa cell tumours with menstrual irregularities and postmenopausal bleeding, the incidence of was $6.47 \%$ similar to other studies..$^{11,15,16,20,27,36}$ One case of synchronous endometrial carcinoma was diagnosed, also reported in other studies. ${ }^{16,27,39}$. In our study there was a case of Sertolileydig cell tumour, conceived after surgery and delivered at term. Metastases to the ovaries are relatively frequent with the most common being from the endometrium, breast, colon, stomach, and cervix. ${ }^{39}$ In our study there was one metastasis was from colonic carcinoma.

Late stage presentation was encountered in $86 \%$ of epithelial carcinomas (Stage III-IV). Delay in presentation is probably responsible for high mortality associated with the disease. Similar delays have been reported in other studies. ${ }^{9,12-14,16,27,39,40}$ Greater awareness among both women with disease and healthcare professionals might result in women presenting earlier with less advanced disease and treatment, leading to better outcomes.

Several limitations of our study deserve comment .This study is institutional based, the study group being small. Therefore, the results obtained may or may not reflect the actual histological pattern and age distribution of ovarian tumours in all Indian women, needs a large group multicentric study. 


\section{CONCLUSION}

The ovarian tumours in our institute represented a wide histological spectrum, commonest being surface epithelial tumours with a similar incidence to other studies .Mucinous cystadenomas subtype was more common than serous cystadenomas, an important implications for research approaches to early detection, prevention and treatment. Amongst malignant ovarian tumours younger age of presentation, advanced stages of the disease is more common, emphasizes the need for investigating for exclusion of malignancy in all the age groups.

\section{ACKNOWLEDGEMENTS}

The authors express their sincere thanks to Dr. Mahalakshmi, Principal Rangaraya Medical College Dr. P.V. Buddha, Superintendent GGH Kakinada, Dr. Rajyalakshmi, HOD, Department of OBG, Dr. KrishnaBabu, Dr. Devi Madhavi, Professors of SPM, Dr. Srujana JR (Path) for their immense help in doing this study.

Funding: No funding sources Conflict of interest: None declared

Ethical approval: The study was approved by the Institutional Ethics Committee

\section{REFERENCES}

1. World Cancer Report 2014. World Health Organization. 2014. Edited by Bernard W. Stewart and Christopher P. Wild Chapter 5.12 p 465.

2. Ferlay J, Soerjomataram I, Dikshit R, Eser S, Mathers C, Rebelo M, et al. Cancer incidence and mortality worldwide: sources, methods and major patterns in GLOBOCAN 2012. International Journal of Cancer. Published online 9 October 2014.

3. Cancer Facts \& Figures 2015: American Cancer Society. Atlanta: American Cancer Society; 2015 Annual Report. 2015, p19. American Cancer Society, Inc., Surveillance Research www.cancer. org. A accessed May 2015.

4. Jayson GC, Kohn EC, Kitchener HC, Ledermann JA. Ovarian cancer. Lancet. 2014;384:1376-88.

5. Saranath D, Khanna A. Current Status of Cancer Burden: Global and Indian Scenario. Biomed Res J. 2014;1(1):1-5.

6. Indian Council of Medical Research. Bangalore: National Cancer Registry Programme-2012. Consolidated Report of Hospital Based Cancer Registries 2009-2011. www.icmr.nic.in/nrcp/report. Acessed January 2015.

7. Kurman RJ, Ie-Ming S. The Origin and Pathogenesis of Epithelial Ovarian Cancer- A Proposed Unifying Theory. Am J Surg Pathol Mar. 2010:34(3):433-43.

8. Ashraf A, Shaikh AS, Akram AIA, Kamal F, Ahmad $\mathrm{N}$. The relative frequency and histopathological pattern of ovarian masses. Biomedica. 2012;2:98102.
9. Sharadha SO, Sridevi T, Renukadevi, Gowri R, Binayak D, Indra V. Ovarian Masses: Changing Clinico Histopathological Trends. The Journal of Obstetrics and Gynecology of India. 2015;65(1):348.

10. Maharjan S. Journal of Chitwan Medical College. 2013;3(6):17-24. Available online at: www.jcmc.cmc.edu.np. Accessed January 2015.

11. Gupta N, Bisht D, Agarwal AK, Sharma VK. Retrospective and prospective study of ovarian tumours and tumour-like lesions. Indian $\mathrm{J}$ Pathol Microbiol. 2007;50(3):525-7.

12. Yogambal M, Arunalatha $\mathrm{P}$, Chandramouleeswari K, Palaniappan V. Ovarian tumours-Incidence and distribution in a tertiary referral center in south India. IOSR J Dental Med Sci. 2014;13(2):74-80.

13. Makwana H, Maru A, Lakum N, Agnihotri A, Trivedi N, Joshi J. The Relative Frequency And Histopathological Pattern Of Ovarian Masses - 11 Year Study At Tertiary Care Centre International Journal of Medical Science and Public Health. 2014;3(1):81-4.

14. Bista KDB. Incidence, Histological Types and Age at Presentation of Borderline and Malignant Ovarian Tumours at a Tertiary Institute in Nepal. NJOG. 2014;9(2 Suppl 18):11-6.

15. Abdullah LS. Histopathological pattern of ovarian neoplasms and their age distribution in the western region of Saudi Arabia. Saudi Med J. 2012;33(1):615.

16. Zaman S, Majid S, Hussain M, Chughtai O, Mahboob J, Chughtai S. A retrospective study of ovarian tumours and tumour-like lesions. J Ayub Medical College. 2010;22(1):104-8.

17. Blaustein A. Pathology of the Female Genital Tract. 2nd EDITION Springer 1982, pp 449-463.

18. Cass DL, Hawkins E, Brandt MC, Chintagumpala M, Bloss RS, Milewicz AL et al. Surgery of ovarian masses in infants, children, and adolescents: 102 consecutive patients treated in a 15 -year period. $\mathbf{J}$ Pediatr Surg. 2010;45:135-9.

19. Manivasakan J, Bupathy Arounassalame A study of benign adnexal masses. Int $\mathrm{J}$ Reprod Contracept Obstet Gynaecol. 2012;1(1):12-6.

20. Jha R, Karki S. Histological pattern of ovarian tumors and their age distribution. Nepal Med Coll J. 2008;10(2):81-3.

21. Iyokec A, Ifaedike CO, Nnbue CC, Nkwo PO, Ezogwo EC, Edosuyi.L et al A ten year review of Ovarian Cancer in Enugu. South East Nigeria Africo Medic Journal. 2011:2(1):8-12.

22. Fuh KC, Shin JY, Brooks RA, Urban RR, et al. Survival differences of Asian and Caucasian epithelial ovarian cancer patients in the United States. Gynecologic Oncology. 2015;136(3):491-7.

23. Rice MS, Murphy MA, Tworoger SS. Tubal ligation, hysterectomy and ovarian cancer: A meta-analysis. J Ovarian Res. 2012;5:13.

24. Casiano ER, Trabuco EC, Bharucha AE, Weaver AL, Schleck CD, Melton LJ, et al. Risk of 
Oophorectomy After Hysterectomy. Obst \& Gynecol. 2013;121(5):1069-74.

25. Salpingectomy for ovarian cancer prevention. Committee Opinion No 62 O American College of Obstetricians and Gynaecologists. Obstet Gynaecol Jan 2015; Committee on Gynecologic Practice 125279-81 www.acog.org. Accessed on 20 may 2015.

26. Mondal SK, Banyopadhayay R, Nag DR, Roychowdhury S, Mondal PK, Sinha SK. Histologic pattern, bilaterality and clinical evaluation of 957 ovarian neoplasms: a10 year study in a tertiary hospital of eastern India. J Cancer Res Ther. 2011;7(4):433-7.

27. Bhagyalakshmi A, Sreelekha A, Sridevi S, Chandralekha J, Parvathi G, Venkatalakshmi A. Prospective study of histopathological patterns of ovarian tumours in a tertiary care centre. Int $\mathrm{J}$ Res Med Sci. 2014;2:448-56

28. Sharma I, Sarma U, Dutta UC. Pathology of Ovarian Tumour-A Hospital Based Study. International journal of medical science and clinical Invention. 2014;1(6):284-6.

29. Sung PL, Chang YH, Chao KC, Chuang CM. Global distribution pattern of histological subtypes of epithelial ovarian cancer: a database analysis and systematic review. Task Force on Systematic Review and Meta-analysis of Ovarian Cancer.

30. Scully RE. Tumors of the Ovary and Maldeveloped Gonads. Hartmann WH, Cowan WR (eds) Atlas of Tumor Pathology, Second Series, Armed Forces Institute of Pathology: Washington, DC, 1979; 239312 .

31. McKenney JK, Soslow RA, Longacre TA. Ovarian mature teratomas with mucinous epithelial neoplasms: morphologic heterogeneity and association with pseudomyxoma peritonei. Am J Surg Pathol. 2008;32(5):645-55.

32. Parveen S, Hakim S, Fatim Z. Mature Cystic Teratoma Of The Ovary Associated With Contralateral Mucinous Cystadenoma: a Case Report. Indian Journal of Applied Research. 2012;1(12):176-7.
33. Brown J, Frumovitz M. Mucinous tumors of the ovary: current thoughts on diagnosis and management. Curr Oncol Rep. 2014;16(6):389.

34. Bodal VK, Jindal T, Bal MS, Bhagat R, Kaur S, Mall $\mathrm{N}$, et al. Clinico - Pathological Study of Ovarian Lesions. Reasearch \& Reviews: Journal Of Medical and Health Sciences. 2014;3(10):98-103.

35. Kuladeepa AVK, Muddegowda PH, Lingegowda JB, Doddikoppad MM, Basavaraja PK, et al. Histomorphological study of 134 primary ovarian tumors. Advance Laboratory Medicine International. 2011;1(4):69-82.

36. Pilli GS, Suneeta KP, Dhaded AV, Yenni VV. Ovarian tumours: a study of 282 cases. J Indian Med Assoc. 2002;100(7):420-4.

37. Kanthikar SN, Dravid NV, Doere PN, Nikumbh DB, Suryavanshi KH. Clinico-Histopathological Analysis of Neoplastic and Non-Neoplastic Lesions of the Ovary: A 3-Year Prospective Study in Dhule, North Maharashtra. India J Clin Diagn Res. 2014;8(8):FC04-7.

38. Yoo SC, Chang KH, Lyu MO, Chang SJ, Ryu HS, Kim HS. Clinical characteristics of struma ovarii. J Gynecol Oncol. 2008;9(2):135-8.

39. Seiden MV. "Gynaecologic Malignancies". In Longo DL, Kasper DL, Jameson JL, Fauci AS, Hauser SL, Loscalzo J. Harrison's Principles of Internal Medicine (18th ed.). McGraw-Hill. 2012; 810-813.

40. Wasim T, Majroh A, Siddiq S. Comparison of clinical presentation of benign and malignant ovarian tumours. J Pak Med Assoc Jan. 2009;59(1):18-21.

Cite this article as: Soumini G, Sarella LK, Lakshmi Chaveli V, Gurugubelli S. Scenario of ovarian mass lesions at a teaching hospital in andhra pradesh India. Int J Reprod Contracept Obstet Gynecol 2015;4:9829. 